\title{
Elevated Ambient Temperature Differentially Affects Virus Resistance in Two Tobacco Species
}

\author{
L. Ma, X. Huang, R. Yu, X. L. Jing, J. Xu, C. A. Wu, C. X. Zhu, and H. M. Liu
}

State Key Laboratory of Crop Biology, College of Life Sciences, Shandong Agricultural University, Tai'an, Shandong, China. Accepted for publication 5 October 2015.

\begin{abstract}
Ma, L., Huang, X., Yu, R., Jing, X. L., Xu, J., Wu, C. A., Zhu, C. X., and Liu, H. M. 2016. Elevated ambient temperature differentially affects virus resistance in two tobacco species. Phytopathology 106:94-100.

Antiviral defense of plants is usually enhanced by an elevated temperature under natural conditions. In order to better understand this phenomenon, we carried out temperature shift experiments with Nicotiana glutinosa plants that were infected with Potato virus $X$ $(\mathrm{PVX})$ or the necrotic strain of Potato virus $Y\left(\mathrm{PVY}^{\mathrm{N}}\right)$. The virus titer of the plants was found to be much lower when they were maintained at $30^{\circ} \mathrm{C}$ compared with $22^{\circ} \mathrm{C}$, particularly in the upper leaves. PVX

resistance at $30^{\circ} \mathrm{C}$ persisted for a short period even when temperature was shifted back to $22^{\circ} \mathrm{C}$. In contrast, $N$. benthamiana lost the virus resistance immediately after the temperature dropped to $22^{\circ} \mathrm{C}$. Expression analysis of two RNA-dependent RNA polymerases in $N$. glutinosa (NgRDR) showed that a 12-day treatment at $30^{\circ} \mathrm{C}$ increased the expression of $N g R D R 1$, while $N g R D R 6$ was not affected. In addition, the $N g R D R 6$ mRNA level correlated with the PVX titer but was unaffected by PVYN infection. These observations indicate that PVX and PVYN, although they are both RNA viruses, might trigger different defense responses at elevated temperatures. Our study provides valuable data for a better understanding of the temperature-regulated host virus interaction.
\end{abstract}

As a sequence-specific surveillance mechanism, RNA silencing is triggered by double-stranded RNA (dsRNA), which is then processed by Dicer or Dicer-like proteins into small RNAs of 21 to 24 nucleotides in length. These small interfering RNAs (siRNAs) are subsequently recruited into the Argonaute-containing RNAinduced silencing complex (RISC), initiating the degradation of homologous RNAs (Carmell and Hannon 2004; Eamens et al. 2008; Qi and Hannon 2005). RNA silencing plays a critical role in plant defense against RNA viruses (Unver and Budak 2009). dsRNA synthesized by viral RNA-directed RNA polymerases (RDRs) triggers RNA silencing at the initiation stage of the virus-induced RNA silencing (Ahlquist 2002; Meister and Tuschl 2004; Ruiz et al. 1998; Unver and Budak 2009). An amplification process depending on host RDRs is then involved in RNA silencing, enabling its persistence with a considerable production of secondary siRNAs (Wassenegger and Krczal 2006). Many viruses encode RNA silencing suppressors (RSSs) to counteract RNA silencing and render hosts more susceptible to viruses (Burgyán and Havelda 2011; Ding and Voinnet 2007; Voinnet et al. 1999).

Plant RDR1 and RDR6 encoded by multigene families are involved in a separate, but overlapping viral resistance mediated by RNA silencing, and are required for the amplification of viral siRNAs (Wang et al. 2010). RDR1 has been found to be inducible by viruses or viroids (Chen et al. 2010; Farshad et al. 2009; Khan et al. 1986; Li et al. 2012; Schiebel et al. 1998). Notably, in Nicotiana benthamiana, there is a natural loss-of-function mutation of RDR1, which may explain the extreme susceptibility of this plant to a wide range of viral species (Yang et al. 2004). The complete cDNA sequence of the $R D R l$ gene from $N$. glutinosa has recently been reported, revealing that the amino acid sequence of $N g R D R 1$ is

Corresponding authors: H. M. Liu; E-mail address: hmliu@sdau.edu.cn,

C. X. Zhu; E-mail address: zhchx@sdau.edu.cn

*The $\boldsymbol{e}$-Xtra logo stands for "electronic extra" and indicates that one supplementary table is published online.

http://dx.doi.org/10.1094/PHYTO-11-14-0300-R

(C) 2016 The American Phytopathological Society
94.54\% identical to $N$. tabacum RDRl (NtRDRl). Cis-acting elements that are involved in stress response are predicted for the 5 '-flanking region of NgRDR1. The expression of Arabidopsis thaliana RDRI and NtRDRI also can be induced by salicylic acid (SA) and is linked to stress resistance (Liu et al. 2009).

RDR6 was found to be involved in the generation of siRNAs in transitive RNA silencing and to be necessary for the amplification of secondary siRNAs during the spread of silencing (Wassenegger and Krczal 2006). Moreover, RDR6 also participates in juvenile development and the production of trans-acting siRNAs in Arabidopsis (Peragine et al. 2004). In antiviral RNA silencing, RDR6-directed dsRNA generation plays a compensatory role in the amplification of viral siRNAs, especially in the absence of RDR1, and some plant species are susceptible to viral infection without RDR6 (Vaistij and Jones 2009; Wang et al. 2010). It has been shown that RDR6 is indispensable for RNA silencing induced by viruses or transgenes in $N$. benthamiana. The reduction of siRNAs is caused by the compromised RNA silencing at low temperatures (Gomez et al. 2008; Qu et al. 2005; Szittya et al. 2003). Meanwhile, RDR6mediated antiviral RNA silencing in $N$. benthamiana was shown to be suppressed when the plants were transformed with an SAinducible RDR1 from N. tabacum (Ying et al. 2010). Recent studies have reported the isolation of the full cDNA of RDR6 in N. glutinosa, with the amino acid sequence revealed to be $95.57 \%$ identical to NbRDR6 in N. benthamiana (Yang et al. 2011). Intriguingly, NgRDR6 can respond to Cucumber mosaic virus (CMV) and abscisic acid, but not to SA or to Tobacco mosaic virus (TMV) and Potato virus $Y$ (PVY) infection (Yang et al. 2011).

The viral resistance of plants is improved at higher temperatures, resulting in attenuation or elimination of the symptoms in laterformed leaves. These recovery phenotypes have been observed in some natural viral infections. As demonstrated in heat therapy experiments, virus-infected plants grown at 35 to $40^{\circ} \mathrm{C}$ exhibited improved viral resistance and recovered from virus infection in 1 or 2 weeks (Mangrauthia et al. 2009). Hyperactive RNA silencing at high temperatures has been shown to reverse the balance of the compatible plant-virus interaction (Szittya et al. 2003; Velazquez et al. 2010). Our previous work revealed that $30^{\circ} \mathrm{C}$ was the turning 
point at which $N$. glutinosa recovered from Potato virus $X$ (PVX) and the necrotic strain of PVY (PVYN) infection (Sun et al. 2008).

With global warming, it is likely that the interaction and balance between hosts and viruses will be changed. Therefore, a better understanding of the effects of elevated temperatures on antiviral defense in plants is of considerable epidemiological importance. In the present study, we examined the effects of $30^{\circ} \mathrm{C}$ heat therapy and temperature shift on the resistance of two tobacco species against PVX and $\mathrm{PVY}^{\mathrm{N}}$, and investigated the induction pattern of $N g R D R l$ and $N g R D R 6$ under these conditions.

\section{MATERIALS AND METHODS}

Plant materials. Wild-type $N$. benthamiana and $N$. glutinosa plants were grown in a growth chamber under a 14-h light and 10-h dark regime at $22^{\circ} \mathrm{C}$.

Temperature shift assay. $N$. glutinosa plants with eight leaves were mechanically inoculated with PVX or PVYN and kept at $22^{\circ} \mathrm{C}$ for 14 days to allow for the development of symptoms. Potassium phosphate buffer (50 mM, pH 7.0)-inoculated plants were taken as mock. The plants were then divided into five groups, each consisting of six individual plants. One control group was maintained at $22^{\circ} \mathrm{C}$, while the other four groups were shifted to $30^{\circ} \mathrm{C}$, one group every 3 days. After the first group being treated for 12 days, the upper and lower leaves of all groups were separately collected at the same time. This ensures the plants of all groups were at the same developmental stage. The newly emerged leaves with a main vein of at least $2 \mathrm{~cm}$ long were regarded as upper leaves, while the infected leaves above the inoculated leaf were considered as lower leaves. The collected samples were used in the following enzyme-linked immunosorbent assay (ELISA) and RNA hybridization assay. Each individual experiment was carried out three times.

High temperature pretreatment assay. Four groups of eight-leaf-stage $N$. glutinosa plants (with each group consisting of six individual plants) were first grown at $30^{\circ} \mathrm{C}$ for $1,4,8$, or 12 days, and subsequently inoculated with PVX. The plants were then grown for another 7 days at $22^{\circ} \mathrm{C}$ for symptom observation and virus detection. One group remained at $22^{\circ} \mathrm{C}$ throughout the experiment and served as the control. After 7 days, the upper leaves (determined with the same criteria described above) of temperature shift assay were collected for ELISA analysis. Each individual experiment was carried out three times.

In order to investigate the duration of the enhanced virus resistance of $N$. glutinosa when the ambient temperature declined, four groups (with each group consisting of six individual plants) of eight-leaf-stage $N$. glutinosa plants were grown at $30^{\circ} \mathrm{C}$ for 12 days and subsequently shifted to $22^{\circ} \mathrm{C}$ for $1,4,8$, or 12 days. The plants were then inoculated with PVX and grown for another 7 days at $22^{\circ} \mathrm{C}$ for symptom development, and the upper leaves were collected for ELISA detection. Each individual experiment was carried out three times.

In order to investigate the effect of high temperatures on the initial virus infection, eight-leaf-stage $N$. glutinosa plants of the group pretreated at $30^{\circ} \mathrm{C}$ for 12 days $\left(30^{\circ} \mathrm{C} \mathrm{P}\right)$ and the group without pretreatment $\left(22^{\circ} \mathrm{C}\right)$ were mechanically inoculated with PVX and maintained at $22^{\circ} \mathrm{C}$, while another group was kept at $30^{\circ} \mathrm{C}$ after PVX inoculation. After another 7 days, the upper leaves were collected for ELISA analysis and RNA hybridization. Each individual experiment was carried out three times.

Virus isolation. PVX and PVYN were propagated on N. tabacum 'NC89' plants and harvested for virus isolation using the method of Shepard and Uyemoto (1976). Briefly, infected tissues were homogenized in $0.05 \mathrm{M}$ borate buffer ( $\mathrm{pH} 7.5$ ) containing $0.02 \mathrm{M}$ citric acid, $0.01 \mathrm{M}$ EDTA, urea at $50 \mathrm{mg} / \mathrm{ml}$, and $0.01 \%$ $\beta$-mercaptoethanol. The extract was strained through two layers of etamine, shaken with $3 \%$ Triton X-100, $0.1 \mathrm{M} \mathrm{NaCl}$, and $5 \%$ polyethylene glycol 6000 for $1.5 \mathrm{~h}$, and then stored at $4{ }^{\circ} \mathrm{C}$ for $3 \mathrm{~h}$.
After centrifugation, the supernatant was removed and the pellet was suspended in $0.05 \mathrm{M}$ sodium borate buffer $(\mathrm{pH} 7.5)$ and transferred onto a sucrose gradient (layers ranging from 10 to $40 \%$ sucrose). Ultracentrifugation was carried out using a JA25.50 rotor (Beckman Coulter, CA) at 25,000 rpm for $2.5 \mathrm{~h}$. The viral bands were carefully removed with an Isco Density Gradient fractionator (ISCO, Lincoln, NE). The isolated viruses were then proliferated on $N$. glutinosa for the viral challenge assay.

Virus inoculation. Fresh inocula for each experiment were prepared from virus-infected $N$. glutinosa leaves. One gram of infected leaf tissue was ground in $10 \mathrm{ml}$ of $50 \mathrm{mM}$ potassium phosphate buffer ( $\mathrm{pH} 7.0$ ), and two expanded leaves in each plant at the eight-leaf stage were mechanically inoculated using quartz sand.

ELISA detection. Relative virus level was detected by indirect ELISA according to the method of Ebel et al. (2002). Samples from all identically treated plants in one group were mixed, and $0.2 \mathrm{~g}$ of mixed leaf tissue was ground in $4 \mathrm{ml}$ of sodium carbonate buffer $(\mathrm{pH}$ 9.6) $(1: 20, \mathrm{~g} / \mathrm{ml})$. Two hundred microliters of extract was added into each well of an ELISA plate and incubated overnight at $4^{\circ} \mathrm{C}$. This incubation was followed by three washes with phosphate-buffered saline ( $\mathrm{pH} 7.0$ ) containing 0.5\% Tween-20 (PBST), and blocking with $0.2 \%$ bovine serum albumin (in PBST) at $37^{\circ} \mathrm{C}$ for $2 \mathrm{~h}$. After three PBST washes, diluted serum $(1: 1,000)$ from virus (PVX or $\mathrm{PVY}^{\mathrm{N}}$ )-immunized BALB/c mice was added to each well. The sealed plate was incubated for $1 \mathrm{~h}$ at $37^{\circ} \mathrm{C}$. After PBST washes, horseradish peroxidase (HRP)-conjugated goat-antimouse $\mathrm{IgG}$ (Dingguo, Beijing, China) (1: 2,000) was applied to each well. After incubation and washing as above, o-phenylenediamine solution was added to each well and incubated for $20 \mathrm{~min}$. The enzymatic reaction was stopped with $25 \mu \mathrm{l}$ of $0.3 \mathrm{M} \mathrm{NaOH}$. The optical density (OD) of each well was measured at $492 \mathrm{~nm}$ using an ELISA reader (Thermo, Shanghai, China). The OD values of the mock controls (PBS-inoculated plants) were set to zero, and the relative virus levels after the different treatments were normalized using the ELISA OD values of the corresponding PVX- or PVYNinfected plants cultivated at $22^{\circ} \mathrm{C}$ (set as $100 \%$ ). Each OD value represents the mean of three wells of one mixed sample from six plants; the error bars represent the standard deviation (SD) of three repeated measurements. Significant differences between two groups were determined with a two-tailed Student's $t$ test, and a $P$ value of $<0.05$ was considered statistically significant. GraphPad Prism 5 software for Windows (GraphPad Software, San Diego, CA) was used for figure preparation. Each individual experiment was carried out three times.

mRNA and siRNA hybridization analysis. Extraction of total RNA and low-molecular-weight RNA from leaf samples and northern blot analysis were carried out as described previously (Jing et al. 2011). Aliquots of total RNA $(40 \mu \mathrm{g})$ for each sample were separated on $1 \%$ formaldehyde agarose gels and transferred to Hybond-N+ membranes (GE Healthcare, UK) by upward capillary transfer in $20 \times$ SSC buffer. A 431-bp NgRDR1 fragment (nucleotides 142 to 572 of EF646264), a 509-bp NgRDR6 fragment (nucleotides 1 to 509 of FJ490363), a 681-bp fragment (FJ461343: nucleotides 4486 to 5166 of the PVX genome), and an 801-bp fragment (AB270705: nucleotides 8553 to 9353 of the PVY genome) were used as probes for the detection of RDRs, PVX, and PVYN mRNAs, respectively. Hybridization intensity was measured and analyzed by the software Image $J$ (National Institutes of Health, NIH). First, relative density values for $30^{\circ} \mathrm{C}$ treatment samples as well as the controls $\left(22^{\circ} \mathrm{C}\right)$ were calculated using the percent value for the loading-control in the same lane, and the adjusted density values for $30^{\circ} \mathrm{C}$ treatment samples were calculated by dividing by the relative density of the corresponding control $\left(22^{\circ} \mathrm{C}\right)$ band in each group. The level in tissue from $22^{\circ} \mathrm{C}$ was arbitrarily designed as 1.0 .

For siRNA detection, $20 \mu \mathrm{g}$ of low-molecular-weight RNAs was separated on a $15 \%$ polyacrylamide- $7 \mathrm{M}$ urea gel, and transferred to 
Hybond-N+ membranes in $0.5 \times \mathrm{TBE}$ at $0.8 \mathrm{~mA} / \mathrm{cm}^{2}$ for $1 \mathrm{~h}$. The membranes were then UV cross-linked, incubated at $80^{\circ} \mathrm{C}$ for $2 \mathrm{~h}$, and then stored at $4^{\circ} \mathrm{C}$ until further use. The probe used in the analysis of viral siRNA was the same as that used for the PVX and PVYN mRNA northern blot.

\section{RESULTS}

Effect of heat therapy on infection with PVX and PVYN in $N$. glutinosa. The temperature shift experiments showed that both PVX- and PVYN-infected $N$. glutinosa plants recovered over time after the temperature was increased from 22 to $30^{\circ} \mathrm{C}$. The symptoms of the newly emerging upper leaves progressively attenuated and failed to appear on new leaves at day 6 for PVX and at day 9 for PVYN, while visible viral symptoms persisted in the infected lower leaves (data not shown). ELISA analyses agreed with these observations (Fig. 1A and B). Northern blot analyses revealed that virus accumulation in the upper leaves rapidly decreased and approached undetectable levels at 6 days after the plants had been shifted to $30^{\circ} \mathrm{C}$ for PVX (Figs. $1 \mathrm{~A}$ and $2 \mathrm{~A}$ ) and at
A

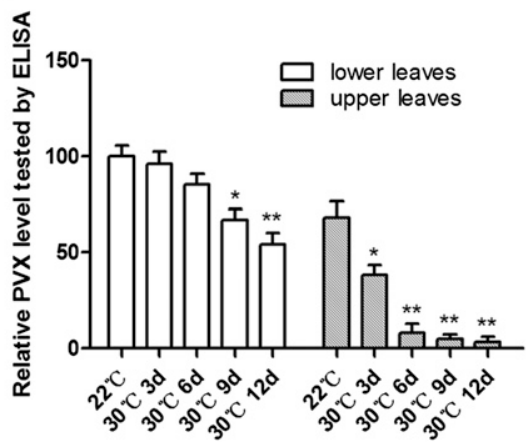

B

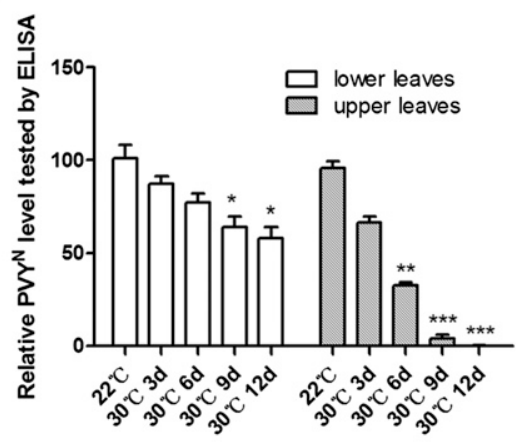

Fig. 1. Virus accumulation of Potato virus $X(\mathrm{PVX})$-infected or Potato virus $Y$ necrosis strain $\left(\mathrm{PVY}^{\mathrm{N}}\right)$-infected Nicotiana glutinosa during 12 days of $30^{\circ} \mathrm{C}$ treatment. A, PVX accumulation and $\mathbf{B}, \mathrm{PVY}^{\mathrm{N}}$ accumulation in the upper and lower leaves of $N$. glutinosa. Plants kept at $30^{\circ} \mathrm{C}$ for 3 days were denoted as $30^{\circ} \mathrm{C} 3 \mathrm{~d}$; plants kept at $30^{\circ} \mathrm{C}$ for 6 days were denoted as $30^{\circ} \mathrm{C} 6 \mathrm{~d}$ and so on. The optical density (OD) values of the mock control were set to zero and the relative virus levels were normalized using the OD values of the corresponding PVX- or PVY ${ }^{\mathrm{N}}$-infected plants cultivated at $22^{\circ} \mathrm{C}$, which were set to $100 \%$. All statistical tests were two-tailed and a $P$ value $<0.05$ was considered statistically significant, denoted as *; $P$ value $<0.001$ denoted as $* *$; and $P$ value $<0.0001$ denoted as $* * *$.

A
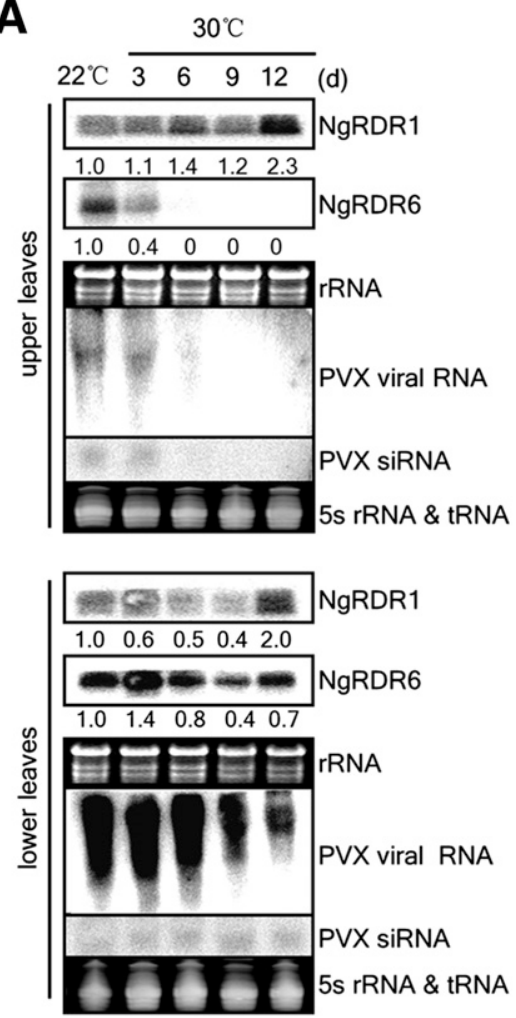

B
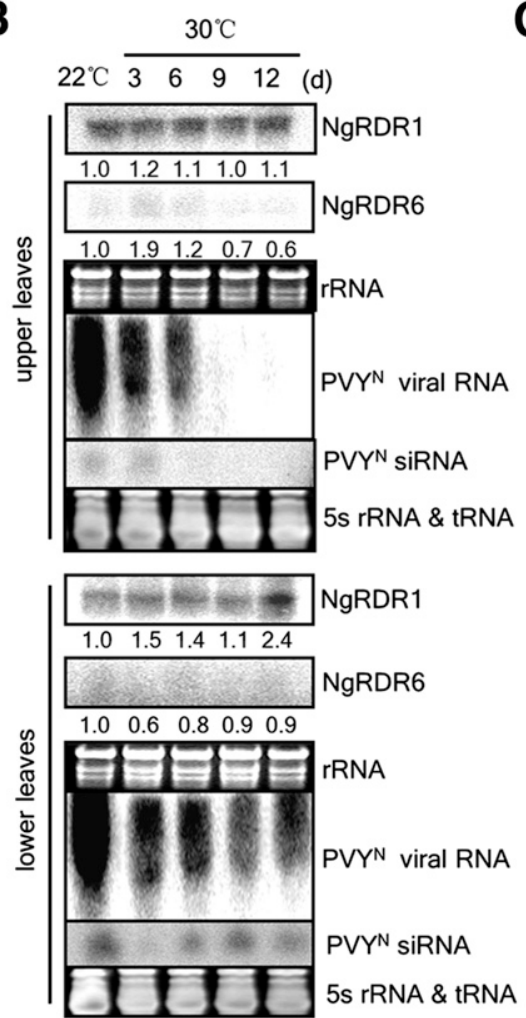

C

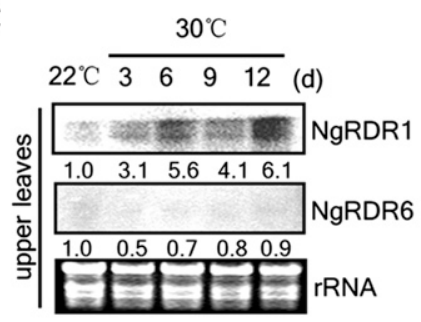

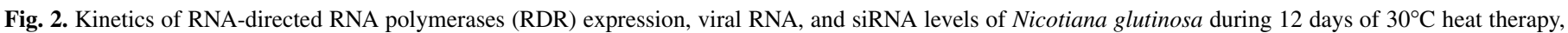

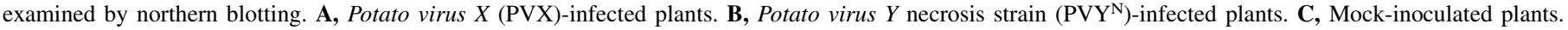

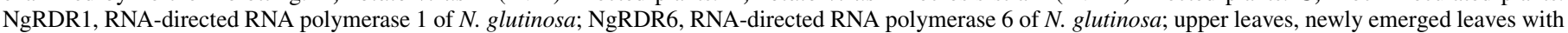

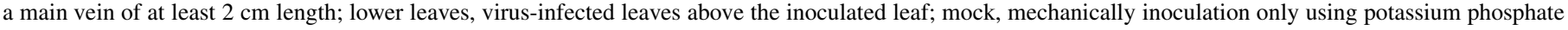

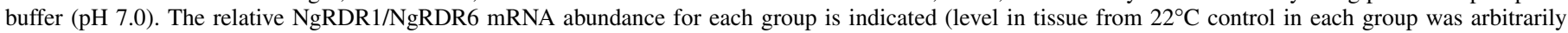

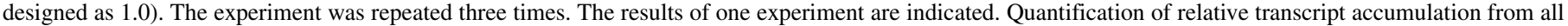
replicates is provided in Supplementary Table S1. 
9 days for PVYN (Figs. 1B and 2B). Virus accumulation in the lower leaves also decreased gradually during $30^{\circ} \mathrm{C}$ treatment. PVX and PVYN were still detectable in the lower leaves after the 12-day treatment at $30^{\circ} \mathrm{C}$, but the upper leaves had almost completely recovered from virus infection at that time (Figs. 1 and 2 ). We also detected virus siRNA in both the upper and lower leaves in the $30^{\circ} \mathrm{C}$-treated plants by northern blotting. Both PVXsiRNAs and $\mathrm{PVY}^{\mathrm{N}}$-siRNAs in the upper leaves were reduced to an undetectable level after 6-day cultivation at $30^{\circ} \mathrm{C}$ in accordance with the decreasing virus titer (Fig. 2). Nonetheless, no obvious change in the siRNA level was observed in the lower leaves during the 12 -day cultivation at $30^{\circ} \mathrm{C}$.

Different expression patterns of RDRs in response to elevated temperature and virus infection. Previous studies have shown that RDR1 and RDR6 are involved in separate but overlapping antiviral RNA silencing of plants. We therefore analyzed the expression pattern of RDRs in N. glutinosa under different treatment conditions by northern blotting. The results showed that the expression of $N g R D R l$ was influenced by elevated temperature, this is seen in the increased level of $\mathrm{NgRDR} 1 \mathrm{mRNA}$ observed after 12 -day $30^{\circ} \mathrm{C}$ treatment both in virus-inoculated and mock-inoculated $N$. glutinosa plants compared with the plants that remained at $22^{\circ} \mathrm{C}$. The upregulation of $N g R D R l$ in the upper leaves of $\mathrm{PVY}^{\mathrm{N}}$-infected plants was not observed (Fig. 2). This indicates that the high temperature could induce the expression of $N g R D R l$, and the continuous cultivation at the higher temperature results in a higher level of NgRDR 1 transcript accumulation at day 12 .

Unlike $\mathrm{NgRDR} 1, \mathrm{NgRDR} 6$ did not respond to $30^{\circ} \mathrm{C}$ treatment but was affected by PVX infection and its expression seemed to correlate with the PVX levels both in the lower and upper leaves (Fig. 2A). Along with the reduction in viral RNA, $N g R D R 6$ mRNA decreased and reached an undetectable level when PVX symptoms failed to appear on the newly emerging upper leaves (Fig. 2A). Nonetheless, NgRDR6 levels were similarly low in PVYNinoculated and mock-inoculated plants (Fig. 2B). This experiment was repeated three times. The results of one representative experiment are shown. Relative mRNA for all three replicates are given in Supplementary Table S1.

Effect of $30^{\circ} \mathrm{C}$ pretreatment on $\mathrm{PVX}$ resistance in N. glutinosa. As mentioned above, the elevated temperature promoted the antiviral defense of $N$. glutinos $a$ and freed the newly emerging leaves of infected plants from the virus. In order to further investigate the effect of higher temperatures on antiviral resistance, $30^{\circ} \mathrm{C}$ pretreatment experiments were carried out. Groups of $N$. glutinosa plants were first grown at $30^{\circ} \mathrm{C}$ for different periods of time, subsequently inoculated with PVX, and then further grown at $22^{\circ} \mathrm{C}$. ELISA analyses showed that pretreatment at $30^{\circ} \mathrm{C}$ for 1 day had no significant impact on the PVX levels compared with the $22^{\circ} \mathrm{C}$ control, while pretreatment for 4 days showed a very significant difference. The plants pretreated at $30^{\circ} \mathrm{C}$ for 8 days accumulated quite low PVX levels, and little virus was detected in the plants pretreated for 12 days (Fig. 3A).

Next, we examined the duration of the enhanced virus resistance of $N$. glutinosa when the ambient temperature declined. In this assay, $N$. glutinosa plants were grown at $30^{\circ} \mathrm{C}$ for 12 days and subsequently shifted to $22^{\circ} \mathrm{C}$ for 1 to 12 days before being inoculated with PVX. The results revealed that virus accumulated at lower levels in the plants that were shifted to $22^{\circ} \mathrm{C}$ for 1 and 4 days before PVX inoculation, whereas plants grown at $22^{\circ} \mathrm{C}$ for 8 and 12 days before inoculation developed visible symptoms in the upper leaves by 7 days postinoculation (dpi). This observation was consistent with high PVX levels assessed by ELISA. The PVX levels of the plants growing for 12 days at $22^{\circ} \mathrm{C}$ before inoculation did not significantly differ from those of the control plants grown at $22^{\circ} \mathrm{C}$ (Fig. 3B).

Different effects of elevated temperature on PVX resistance in $N$. glutinosa and $N$. benthamiana. Experiments were conducted to determine whether or not higher temperature protects the host plant from initial virus infection. Two groups of $N$. glutinosa plants, a 12 -day $30^{\circ} \mathrm{C}$ pretreated group $\left(30^{\circ} \mathrm{C} \mathrm{P}\right)$ and a $22^{\circ} \mathrm{C}$ group, were mechanically inoculated with PVX and then kept at $22^{\circ} \mathrm{C}$, while another group was continuously kept at $30^{\circ} \mathrm{C}$ before and after PVX inoculation. At $7 \mathrm{dpi}$, the upper leaves of the $22^{\circ} \mathrm{C}$ group developed viral symptoms, while those of the $30^{\circ} \mathrm{C}$ group and the $30^{\circ} \mathrm{C}$ pretreated group showed no PVX symptoms. These observations were supported by ELISA analysis with very low levels of virus detected in the latter two groups (Fig. 4A). Northern blot analysis showed the presence of viral RNAs and siRNAs in the newly emerging leaves of the $22^{\circ} \mathrm{C}$ group, but no detectable viral RNAs and siRNAs in the $30^{\circ} \mathrm{C}$ and $30^{\circ} \mathrm{C}$ pretreatment groups (Fig. 4B).
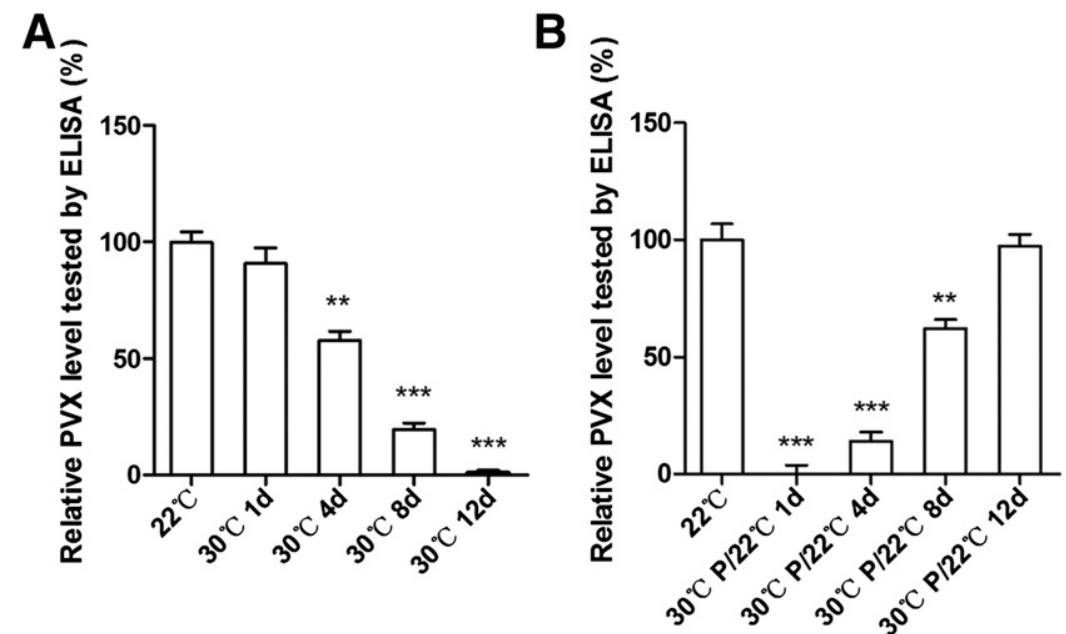

Fig. 3. Effect of $30^{\circ} \mathrm{C}$ pretreatment on Potato virus X (PVX) resistance in Nicotiana glutinosa. A, Effect of different pretreatment time on PVX resistance. B, Duration of the PVX resistance induced by the 12 -day $30^{\circ} \mathrm{C}$ pretreatment $\left(30^{\circ} \mathrm{C} \mathrm{P}\right)$. Plants kept at $30^{\circ} \mathrm{C}$ for 1 day were denoted as $30^{\circ} \mathrm{C} 1 \mathrm{~d}$; plants kept at $30^{\circ} \mathrm{C}$ for 4 days were denoted as $30^{\circ} \mathrm{C} 4 \mathrm{~d}$ and so on; plants kept at $30^{\circ} \mathrm{C}$ for 12 days and then shifted to $22^{\circ} \mathrm{C}$ for 1 day were denoted as $30^{\circ} \mathrm{C} \mathrm{P} / 22^{\circ} \mathrm{C} 1 \mathrm{~d}$; plants kept at $30^{\circ} \mathrm{C}$ for 12 days and then shifted to $22^{\circ} \mathrm{C}$ for 4 day were denoted as $30^{\circ} \mathrm{C} \mathrm{P} / 22^{\circ} \mathrm{C} 4 \mathrm{~d}$ and so on; mock, mechanically inoculation only using potassium phosphate buffer (pH 7.0). Optical density (OD) values of the mock control were set to zero, and relative virus levels were normalized using OD values corresponding PVX-infected plants cultivated at $22^{\circ} \mathrm{C}$, which were set to $100 \%$. All statistical tests were two-tailed and $P$ value $<0.05$ was considered statistically significant; $P$ value $<0.001$ denoted as **; and $P$ value $<0.0001$ denoted as $* * *$. 
Similar experiments were carried out using $N$. benthamiana. In these plants, PVX accumulation was also reduced at $30^{\circ} \mathrm{C}$, but pretreatment at $30^{\circ} \mathrm{C}$ for 12 days could not protect the plants from PVX infection. PVX accumulation of the pretreated plants was detected at 7 dpi by ELISA and northern blotting, and was only slightly lower than that of the plants kept at $22^{\circ} \mathrm{C}$ (Fig. $4 \mathrm{C}$ and D).

\section{DISCUSSION}

Ambient temperatures not only affect plant growth and development, but also influence the interactions between plants and pathogens. Szittya et al. (2003) suggested a model based on their studies in which, at low temperature, the nonessential RNA silencing machinery is inactivated, but miRNA-mediated essential regulatory functions continue to operate, ensuring normal plant growth. As a cost, plants are more susceptible to viruses and to other molecular parasites at low temperature (Szittya et al. 2003). This coincides with the observations that the attenuation of viral symptoms in infected plants is often associated with a rise in temperature, and some viral diseases are known to break out in the field when ambient temperatures decline (Canto et al. 2009; Gomez et al. 2008; Mangrauthia et al. 2009; Szittya et al. 2003). In our experiments, the symptoms of PVX or PVYN of $N$. glutinos $a$ or
$N$. benthamiana plants became less pronounced or were completely absent in the newly emerging leaves under $30^{\circ} \mathrm{C}$ heat treatment. Nevertheless, when the recovered plants were returned to the $22^{\circ} \mathrm{C}$ environment, the upper leaves of the plants began to develop symptoms again. This indicates a dynamic balance between viral spread and antiviral defense, and that temperature is an important factor through which this balance is regulated.

Our results showed that a temperature of $30^{\circ} \mathrm{C}$ significantly decreased the virus accumulation in the infected plants, particularly in the upper leaves, and the reduced accumulation of virus persisted for a short period in $N$. glutinosa even when the temperature was shifted to $22^{\circ} \mathrm{C}$ (Fig. 3B). This suggests that the elevated temperature has an accumulative effect on the antiviral defense in $N$. glutinosa, and that the 12 -day $30^{\circ} \mathrm{C}$ pretreatment suffices to prevent $N$. glutinosa from virus infection. The virus resistance induced by higher temperature in $N$. glutinosa can persist for a certain period and that the resistance will be lost when the cultivation at the low temperature continues for an extended period. In the $30^{\circ} \mathrm{C}$ heat treatment experiment, viral RNA reduces to a fairly low level, but there is still a substantial amount of viral coat protein $(\mathrm{CP})$ by ELISA. This may be due to the different halflife period of virus proteins and RNAs, and the results could also demonstrate that antivirus RNA silencing plays a considerable
A

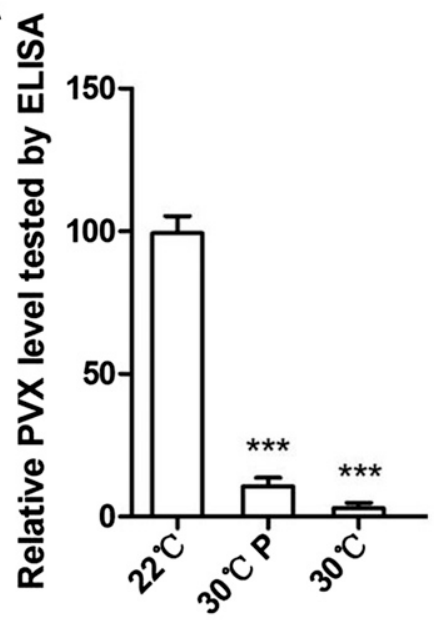

C

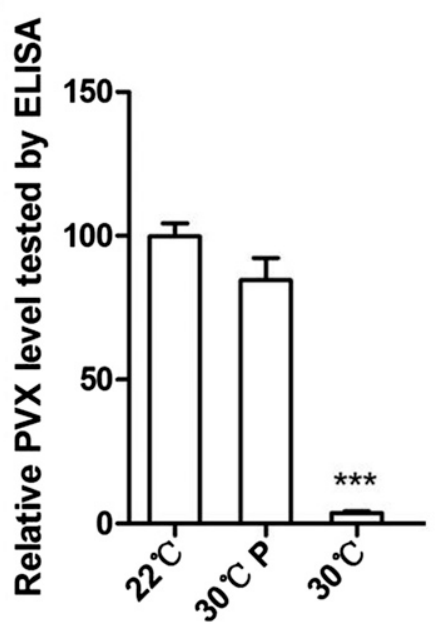

B

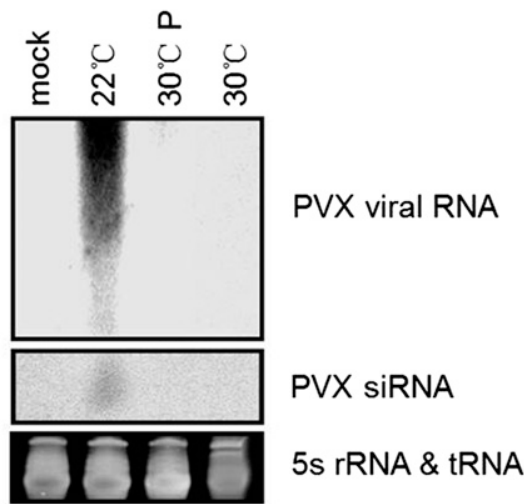

D

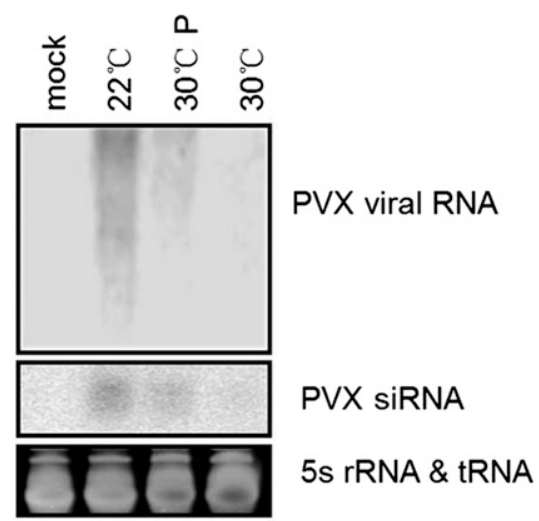

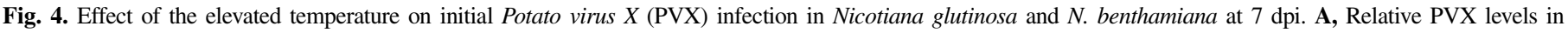

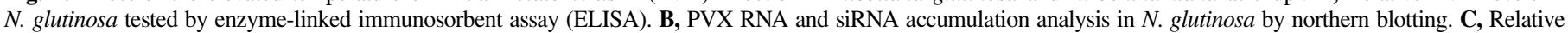

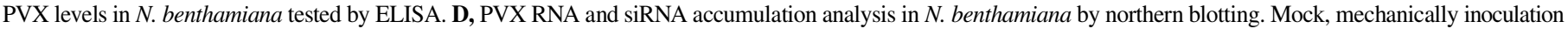

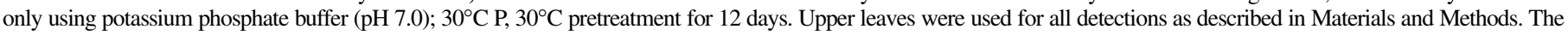

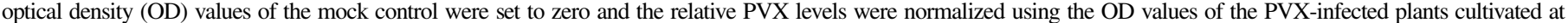
$22^{\circ} \mathrm{C}$, which were set to $100 \%$. All statistical tests were two-tailed and a $P$ value $<0.05$ was considered statistically significant; and $P$ value $<0.0001$ denoted as $* * *$. 
role during the heat-treatment process. The $30^{\circ} \mathrm{C}$ pretreatment experiment also showed that the higher temperature activates the viral defense of $N$. glutinosa and that this enhanced resistance is sufficient to prevent the systemic spreading of PVX from the initially infected sites. Nevertheless, in $N$. benthamiana, reduced accumulation of virus at $30^{\circ} \mathrm{C}$ was lost immediately after the temperature dropped to $22^{\circ} \mathrm{C}$. That is, the viral resistance of $N$. benthamiana induced by the higher temperature is dramatically compromised once the ambient temperature declines. This suggests that different antiviral responses are triggered at higher temperature in these two tobacco species with distinct genetic backgrounds. $N$. glutinosa has two functional RDRs, NgRDR1 and NgRDR6, while $N$. benthamiana features a functional RDR6 (NbRDR6) and a natural loss-of-function mutation in RDR1 (Yang et al. 2004).

Previous studies have shown that low temperatures could inhibit antiviral RNA silencing by compromising the generation of virus-derived siRNAs; conversely, higher temperatures could promote antiviral RNA silencing by increasing the amount of viral siRNAs (Chellappan et al. 2005; Qu et al. 2005; Szittya et al. 2003). Nonetheless, the mechanisms underlying these phenomena have not yet been completely elucidated. In previous investigations, the requirement of RDR1 and RDR6 for viral siRNA generation in antiviral RNA silencing has been demonstrated (Mourrain et al. 2000; Wassenegger and Krczal 2006; $\mathrm{Yu}$ et al. 2003). Using Arabidopsis $r d r$ mutants, antiviral redundancy of RDR1 and RDR6 in viral siRNA generation has been observed, and the two RDRs exhibited specificity in targeting the tripartite positive-strand RNA genome of CMV and difference in siRNA abundance (Garcia-Ruiz et al. 2010; Qi et al. 2009; Wang et al. 2010).

In order to investigate the response of RDRs to higher temperature, we monitored the dynamic expression of $N g R D R 1$ and $N g R D R 6$ genes during a $30^{\circ} \mathrm{C}$ treatment. The results indicated a cumulative effect of the higher temperature on $N g R D R l$. The heat shock element embedded in the 5 '-flanking region of $N g R D R 1$ also supports its involvement in the temperature response (Liu et al. 2009). However, the expression of the $\mathrm{NgRDR6}$ gene was not affected by the elevated temperature. RDR6 is known to be required for juvenile development and the production of transacting siRNAs in Arabidopsis (Peragine et al. 2004). It may be essential for the RDR6 gene to maintain a stable expression level under different ambient temperatures. The natural mutation in the RDRl gene of $N$. benthamiana may potentially explain the different effects of the temperature shift on the two tobacco species. RDRl is inducible at high temperatures and provides a virus defense system for $N$. glutinosa; due to the lack of functional $R D R 1, N$. benthamiana is unable to activate this defense mechanism. In addition, RDR6 of $N$. glutinosa showed different responses to virus infection with its transcript level being affected by PVX but not by PVYN. This indicates that PVX and PVYN might trigger different defense responses in $N$. glutinosa, although they are both RNA viruses. Previous studies showed that the RNA silencing mechanisms directed by RDR1 or RDR6 have functional redundancy, but RDR1 might have a dual role, contributing to salicylic acid-mediated antiviral defense and suppressing the RDR6-mediated antiviral RNA silencing (Ying et al. 2010). The increased expression of $N g R D R 1$ after 12 -day $30^{\circ} \mathrm{C}$ treatment suggests its probable role in the temperature-regulated host-virus interaction. The activities of RDRs or other components in the RISC complex might also be influenced by higher temperature, because the virus resistance of $N$. benthamiana could be improved by an increase in temperature. Antiviral RNA silencing also could be enhanced if high temperature reduces the transcription of RSSs or changes the interaction between suppressors and host. In conclusion, the definite role of these two RDRs and other components of RNA silencing pathway at elevated ambient temperature needs to be further elucidated in future studies.

\section{ACKNOWLEDGMENTS}

This work was supported by the National Science Foundation of Shandong Province (2015ZRB01262), the Research and Development Projects in Colleges and Universities of Shandong Province (J13LE17), National Natural Science Foundation of China (NSFC) (31272113), and Genetically Modified Organisms Breeding Major Projects of China (2009ZX08009-092B).

\section{LITERATURE CITED}

Ahlquist, P. 2002. RNA-dependent RNA polymerases, viruses, and RNA silencing. Science 296:1270-1273.

Burgyán, J., and Havelda, Z. 2011. Viral suppressors of RNA silencing. Trends Plant Sci. 16:265-272.

Canto, T., Aranda, M. A., and Fereres, A. 2009. Climate change effects on physiology and population processes of hosts and vectors that influence the spread of hemipteran-borne plant viruses. Glob. Change Biol. 15: 1884-1894

Carmell, M. A., and Hannon, G. J. 2004. RNase III enzymes and the initiation of gene silencing. Nat. Struct. Mol. Biol. 11:214-218.

Chellappan, P., Vanitharani, R., Ogbe, F., and Fauquet, C. M. 2005. Effect of temperature on geminivirus-induced RNA silencing in plants. Plant Physiol. 138:1828-1841

Chen, H., Tamai, A., Mori, M., Ugaki, M., Tanaka, Y., Samadder, P. P., Miyao, A., Hirochika, H., Yamaoka, N., and Nishiguchi, M. 2010. Analysis of rice RNA-dependent RNA polymerase 1 (OsRDR1) in virus-mediated RNA silencing after particle bombardment. J. Gen. Plant Pathol. 76:152-160.

Ding, S., and Voinnet, O. 2007. Antiviral immunity directed by small RNAs. Cell 130:413-426

Eamens, A., Wang, M. B., Smith, N. A., and Waterhouse, P. M. 2008. RNA silencing in plants: Yesterday, today, and tomorrow. Plant Physiol. 147: 456-468.

Ebel, G. D., Dupuis, A. P., II, Nicholas, D., Young, D., Maffei, J., and Kramer, L. D. 2002. Detection by enzyme-linked immunosorbent assay of antibodies to West Nile virus in birds. Emerg. Infect. Dis. 8:979-982.

Farshad, R., Minoru, T., Julie, S., and Peter, P. 2009. The influence of RNAdependent RNA polymerase 1 on Potato virus $Y$ infection and on other antiviral response genes. Mol. Plant-Microbe Interact. 22:1312-1318.

Garcia-Ruiz, H., Takeda, A., Chapman, E. J., Sullivan, C. M., Fahlgren, N., Brempelis, K. J., and Carrington, J. C. 2010. Arabidopsis RNA-dependent RNA polymerases and dicer-like proteins in antiviral defense and small interfering RNA biogenesis during Turnip mosaic virus infection. Plant Cell 22:481-496.

Gomez, G., Martinez, G., and Pallas, V. 2008. Viroid-induced symptoms in Nicotiana benthamiana plants are dependent on RDR6 activity. Plant Physiol. 148:414-423.

Jing, X. L., Fan, M. N. N., Jia, G., Liu, L. W., Ma, L., Zheng, C. C., Zhu, X. P., Liu, H. M., and Wang, X. Y. 2011. A multifunctional protein encoded by Turkey herpesvirus suppresses RNA silencing in Nicotiana benthamiana. J. Virol. 85:12792-12803.

Khan, Z. A., Hiriyanna, K. T., Chavez, F., and Fraenkel-Conrat, H. 1986. RNA-directed RNA polymerases from healthy and from virus-infected cucumber. Proc. Natl. Acad. Sci. USA 83:2383-2386.

Li, S. W., Yu, F. F., Wang, M., Guo, X. Q., and Li, H. 2012. Molecular characterization of a Nicotiana tabacum NtRDR6 gene. Plant Mol. Biol. Rep. 30:1375-1384.

Liu, Y., Gao, Q., Wu, B., Ai, T., and Guo, X. 2009. NgRDR1, an RNAdependent RNA polymerase isolated from Nicotiana glutinosa, was involved in biotic and abiotic stresses. Plant Physiol. Biochem. 47:359-368.

Mangrauthia, S. K., Singh Shakya, V. P., Jain, R. K., and Praveen, S. 2009. Ambient temperature perception in papaya for Papaya ringspot virus interaction. Virus Genes 38:429-434.

Meister, G., and Tuschl, T. 2004. Mechanisms of gene silencing by doublestranded RNA. Nature 431:343-349.

Mourrain, P., Beclin, C., Elmayan, T., Feuerbach, F., Godon, C., Morel, J. B., Jouette, D., Lacombe, A. M., Nikic, S., Picault, N., Rémoue, K., Sanial, M., Vo, T. A., and Vaucheret, H. 2000. Arabidopsis SGS2 and SGS3 genes are required for posttranscriptional gene silencing and natural virus resistance. Cell 101:533-542.

Peragine, A., Yoshikawa, M., Wu, G., Albrecht, H. L., and Poethig, R. S. 2004. SGS3 and SGS2/SDE1/RDR6 are required for juvenile development and the production of trans-acting siRNAs in Arabidopsis. Genes Dev. 18: 2368-2379.

Qi, X., Bao, F. S., and Xie, Z. 2009. Small RNA deep sequencing reveals role for Arabidopsis thaliana RNA-dependent RNA polymerases in viral siRNA biogenesis. PLoS One 4:e4971.

Qi, Y., and Hannon, G. J. 2005. Uncovering RNAi mechanisms in plants: Biochemistry enters the foray. FEBS Lett. 579:5899-5903. 
Qu, F., Ye, X., Hou, G., Sato, S., Clemente, T. E., and Morris, T. J. 2005. RDR6 has a broad-spectrum but temperature-dependent antiviral defense role in Nicotiana benthamiana. J. Virol. 79:15209-15217.

Ruiz, M. T., Voinnet, O., and Baulcombe, D. C. 1998. Initiation and maintenance of virus-induced gene silencing. Plant Cell. 10:937-946.

Schiebel, W., Pélissier, T., Riedel, L., Thalmeir, S., Schiebel, R., Kempe, D., Lottspeich, F., Sanger, H. L., and Wassenegger, M. 1998. Isolation of an RNA-directed RNA polymerase specific cDNA clone from tomato. Plant Cell. 10:2087-2102.

Shepard, J. F., Uyemoto, J. K. 1976. Influence of elevated temperatures on the isolation and proliferation of mesophyll protoplasts from PVX- and PVY-infected tobacco tissue. Virology. 70:558-560.

Sun, Y. X., Zhang, X. J., Liu, L., Liu, X. J., and Liu, H. M. 2008. High temperatures activate RNA silencing-mediated antiviral defense in tobacco plants. Acta Phytopathol. Sin. 38:58-63.

Szittya, G., Silhavy, D., Molnar, A., Havelda, Z., Lovas, A., Lakatos, L., Banfalvi, Z., and Burgyan, J. 2003. Low temperature inhibits RNA silencing-mediated defence by the control of siRNA generation. EMBO J. 22:633-640.

Unver, T., and Budak, H. 2009. Virus-induced gene silencing, a post transcriptional gene silencing method. Intl. J. Plant Gen. 2009: 198680

Vaistij, F. E., and Jones, L. 2009. Compromised virus-induced gene silencing in RDR6-deficient plants. Plant Physiol. 149:1399-1407.

Velazquez, K., Renovell, A., Comellas, M., Serra, P., Garcia, M. L., Pina, J. A., Navarro, L., Moreno, P., and Guerri, J. 2010. Effect of temperature on RNA silencing of a negative-stranded RNA plant virus: Citrus psorosis virus. Plant Pathol. 59:982-990.

Voinnet, O., Pinto, Y., and Baulcombe, D. 1999. Suppression of gene silencing: A general strategy used by diverse DNA and RNA viruses of plants. Proc. Natl. Acad. Sci. USA 96:14147-14152.

Wang, X. B., Wu, Q., Ito, T., Cillo, F., Li, W. X., Chen, X., Yu, J. L., and Ding, S. W. 2010. RNAi-mediated viral immunity requires amplification of virusderived siRNAs in Arabidopsis thaliana. Proc. Natl. Acad. Sci. USA 107: 484-489.

Wassenegger, M., and Krczal, G. 2006. Nomenclature and functions of RNAdirected RNA polymerases. Trends Plant Sci. 11:142-151.

Yang, H., Wang, M., Gao, Z., Zhu, C., and Guo, X. 2011. Isolation of a novel RNA-dependent RNA polymerase 6 from Nicotiana glutinosa, NgRDR6, and analysis of its response to biotic and abiotic stresses. Mol. Biol. Rep. 38:929-937.

Yang, S. J., Carter, S. A., Cole, A. B., Cheng, N. H., and Nelson, R. S. 2004. A natural variant of a host RNA-dependent RNA polymerase is associated with increased susceptibility to viruses by Nicotiana benthamiana. Proc. Natl. Acad. Sci. USA 101:6297-6302.

Ying, X. B., Dong, L., Zhu, H., Duan, C. G., Du, Q. S., Lv, D. Q., Fang, Y. Y., Garcia, J. A., Fang, R. X., and Guo, H. S. 2010. RNA-dependent RNA polymerase 1 from Nicotiana tabacum suppresses RNA silencing and enhances viral infection in Nicotiana benthamiana. Plant Cell 22:1358-1372.

Yu, D. Q., Fan, B. F., Stuart, A. M., and Chen, Z. X. 2003. Analysis of the involvement of an inducible Arabidopsis RNA-dependent RNA polymerase in antiviral defense. Mol. Plant-Microbe Interact. 16:206-216. 